\title{
NOTES
}

\section{COST CONTAINMENT MAY HAVE A PRICE, BUT IS IT A CRIME? ANALYZING THE BASIS FOR CRIMINALIZING MANAGED CARE CONDUCT}

\author{
Courtney Lyons Snyder*
}

These companies are making a killing, killing people. Shame. ${ }^{1}$

- Jason Calacanis

\section{INTRODUCTION}

A recent transplant case raises an interesting question: Should a managed care organization ("MCO") face criminal prosecution when a patient dies after the MCO's decision to deny payment for treatment? ${ }^{2}$ Is providing such a legal cause of action the solution, or does doing so just put money into the pockets of attorneys rather than into the hands of the injured health care consumer? As a recent case suggests, bad publicity could be as effective a deterrent as any criminal prosecution in changing an MCO's behavior.

Nataline Sarkisyan was a seventeen-year-old California teenager who died while awaiting a liver transplant for which her insurer had refused to pay.

* J.D. Candidate, 2009, University of Pittsburgh School of Law.

1. The Jason Calacanis Weblog, http://calacanis.com/?s=sarkisyan (Dec. 21, 2007, 14:07 PST) (holding no apparent special relationship to the victim, the blogger is one of many members of the general public commenting on the case).

2. For the purposes of this note, "Managed Care Organization" will encompass all forms of health insurance (including HMOs) that "attempt[] not just to pay for, but also to control the cost of, health care services.” Barry R. Furrow et al., Health Law: Cases, Materials and Problems 567 (5th ed. 2004). See generally Jacob S. Hacker \& Theodore R. Marmor, How Not to Think About "Managed Care," 32 U. Mich. J.L. REFORM 661 (1999). 
Sarkisyan began suffering from leukemia, a cancer of the blood, at the age of fourteen and went into remission soon after her initial treatment. ${ }^{3}$ In 2007, at the age of seventeen, her cancer relapsed, and she received a bone marrow transplant from her brother in November of that year. ${ }^{4}$ Despite putting her cancer back into remission, a blood-clotting complication from the bone marrow transplant caused her liver to fail, and she was put on life support. ${ }^{5}$ On December 10th, her oncologist and four members of the organ transplant department at the University of California, Los Angeles ("UCLA") made the first liver transplant request of CIGNA HealthCare ("CIGNA"), the insurer of one of Sarkisyan's parents. ${ }^{6}$ The following day CIGNA denied payment for the transplant, allegedly stating that Nataline was "too sick for the surgery to work," thus deeming it experimental. ${ }^{7}$

On December 20, 2007, under national media scrutiny as a result of protests outside of its Glendale, California office, CIGNA remarkably reversed its initial decision and approved payment for the transplant. ${ }^{8}$ In doing so, CIGNA effectively decided to pay for the transplant out of its pocket, as "experimental treatments" were not covered under Sarkisyan's employer's plan. ${ }^{9}$ However, CIGNA's decision to reverse its initial determination came too late. The Sarkisyan family had already removed their daughter from life

3. David Whelan, Does Cigna Deserve all the Blame?, Forbes, Jan. 8, 2008, available at http://www.forbes.com/healthcare/2008/01/08/sarkisyan-cancer-insurance-biz-healthcare-cz_dw_ 0107cigna.html.

4. Id.

5. Id.; see also Joel Zinberg, Op-Ed, Edwards' Evil Insurance Scam: Twisting Tragedy of Dead Liver Girl, N.Y. Post, Jan. 10, 2008, available at http://www.nypost.com/seven/01102008/postopinion/ opedcolumnists/edwards_evil_insurance_scam_797339.htm (discussing that liver failure following a bone marrow transplant usually results from "veno-occlusive disease or graft-versus-host disease").

6. Compare Whelan, supra note 3 (stating that the insurance coverage was through Nataline's mother's employer), with Zinberg, supra note 5 (stating that the insurance coverage was through Nataline's father's employer).

7. Whelan, supra note 3. Whelan also discusses that Sarkisyan's doctors appealed the decision, arguing that "Sarkisyan would have a $65 \%$ chance of surviving for six months after the liver transplant, based on studies of similar patients" and that she "had an $85 \%$ chance of avoiding a recurrence of cancer because of the successful bone marrow transplant." Id.

8. $I d$.

9. Id. ("Though the company still believed it was experimental, it would pay out of its own pocket (not that of Nataline Sarkisyan's mother's employer) for the procedure."). See generally Corrine P. Parver \& Kimberly Alyson Martinez, Holding Decision Makers Liable: Assessing Liability Under a Managed Health Care System, 51 ADMIN. L. REv. 199, 206 (1999) ("Frequently, HMOs and other third party payors deny payment for experimental treatments, like bone marrow transplants, as not medically necessary because of their overall unproven success rate in general treatment." However, "[t]he meaning of "medically necessary' has been debated by scholars and courts alike, without any clear answer."). For a discussion of self-insured plans see infra note 95. 
support, and she died later that day. ${ }^{10}$ The attorney for the Sarkisyan family has since threatened to bring murder or manslaughter charges against CIGNA because, in his words, the insurer did not want to "take the after-care coverage" and in deciding to deny treatment for this reason had "maliciously killed" the girl. ${ }^{11}$

The public outcry from this case and the public bias against "greedy" insurers may be what is prompting the criminal liability threat. ${ }^{12}$ Managed care has become the new lead paint, tobacco, and gun manufacturer-it is a completely legal industry that is increasingly unpopular with the public. ${ }^{13}$ Unlike those industries, however, civil suits against MCOs face an additional hurdle: ERISA preemption. ${ }^{14}$ As a consequence, a plaintiff's damages have been limited to reimbursement for expenses, which has been unsatisfactory for many, especially those who have lost loved ones due to treatment denial. ${ }^{15}$ Though criminal sanctions would not solve the remedies issue, it could provide the punitive and deterrent aspects for which there seems to have been so much public outcry.

This Note explores the logic behind healthcare insurers' seemingly criminal exempt status, including situations when treatment delay and denial is almost certain to result in death for the insured, and why criminal prosecution is not the answer to the current healthcare debate. The events

10. Whelan, supra note 3 .

11. Cancer Girl's Lawyer Blames CIGNA For Her Death, CBS2.com, Dec. 20, 2007, http://cbs2.com/local/nataline.sarkisyan.CIGNA.2.615167.html. But cf. Zinberg, supra note 5 ("Sarkisyans' insurer authorized payment for three years of treatment for Nataline, including an expensive bone-marrow transplant.").

12. See Zinberg, supra note 5 (discussing that physicians and the public have "good reason" to dislike medical insurers because of their routine denial of claims and treatments and their general bureaucracy).

13. Bryce A. Jensen, Note, From Tobacco to Health Care and Beyond-A Critique of Lawsuits Targeting Unpopular Industries, 86 CoRnell L. Rev. 1334, 1335 (2001).

14. 29 U.S.C. § 1144(a) (2006); see also FURROw ET AL., supra note 2 (discussing that ERISA preempts state law for self-insured plans.); Allen D. Allred \& Don L. Daniel, Upon Further Review: Rush Prudential HMO, Inc. v. Moran and a New Era of Managed Care Organization Liability, 47 ST. LouIs U. L.J. 309, 312-13 (2003) ("[V]irtually all privately employed Americans who receive health benefits as part of their employment are covered by an ERISA plan."); Parver \& Martinez, supra note 9, at 227 ("Claims based on a decision to deny or limit coverage generally are preempted under ERISA.”); W. Devin Resides, Note, Holding HMO's Liable in the New Millennium: New Theories With An Old Twist, 27 OKLA. CiTY U. L. Rev. 419, 437 (2002) ("ERISA bars two traditional types of recovery available in tort actions, compensatory and punitive damages.”). But see Travis J. Ketterman, The Supreme Court Endorses the Right to Second Opinions for HMO Participants, 91 ILL. B.J. 66, 71 (2003) (“[M] edical necessity decisions are both medical-care and policy-coverage decisions. Because these decisions are in both classes, they are not preempted by ERISA.").

15. Allred \& Daniel, supra note 14 , at 313. 
surrounding Nataline Sarkisyan's death are outlined above for purposes of showing the sensitive nature of such cases and the strong public reaction against the insurer. This paper does not purport to determine whether criminal charges would be warranted in CIGNA's case since many of the facts are in dispute. Part I will explore why a move toward criminal prosecutions seems almost inevitable in light of ERISA's limitations on damages and the public response to the healthcare crisis. Part II will look at why criminal homicide charges against a healthcare insurer seem unlikely to succeed, and Part III will examine why such prosecutions are not the solution to the current healthcare debate. Finally, Part IV will postulate why and how Congress should step in to fill ERISA's gaping holes.

\section{The Movement from Civil to Criminal Liability}

\section{A. ERISA}

In the past, most disputes against insurers were made via a state law complaint in tort. ${ }^{16}$ However, with the evolution of the federal Employee Retirement Income Security Act ("ERISA") in 1974, many of these cases were removed to federal court under the preemption clause. ${ }^{17}$ This preemption signaled a victory for the managed care industry, which once faced potentially ruinous damages exposure under state law. ${ }^{18}$ Remedies under ERISA are limited to the cost of the denied treatment, and typically there is no remedy at all if a patient dies as a result of a treatment denial by an MCO. ${ }^{19}$

For a period of time the Supreme Court seemed to cut back on ERISA preemption. ${ }^{20}$ Nevertheless, in the consolidated cases of Aetna Health Inc. $v$. Davila and CIGNA HealthCare of Texas, Inc. v. Calad, the Court ruled that ERISA completely preempts state law causes of action for wrongful denial of benefits that involve "pure eligibility decisions." ${ }^{21}$ In these cases, a participant and a beneficiary sued their respective Health Maintenance Organizations

16. Id.

17. See 29 U.S.C. $\S 1144$ (2006).

18. See Allred \& Daniel, supra note 14, at 309-10.

19. See id. at 313 .

20. See, e.g., Rush Prudential HMO, Inc. v. Moran, 536 U.S. 355 (2002).

21. Aetna Health, Inc. v. Davila, 542 U.S. 200, 221 (2004); see also Pegram v. Herdrich, 530 U.S. 211, 228 (2000) ('[P]ure 'eligibility decisions' turn on the plan's coverage of a particular condition or medical procedure for its treatment. 'Treatment decisions,' by contrast, are choices about how to go about diagnosing and treating a patient's condition: given a patient's constellation of symptoms, what is the appropriate medical response?"). 
("HMOs") for failure to exercise ordinary care when the HMOs denied certain treatments and services recommended by their treating physicians in violation of a Texas statute. The Court held that ERISA completely preempted the state cause of action because (a) any legal duty under the state statute arose from the administration of an ERISA-regulated plan and (b) the HMOs were denying payment based on eligibility under the plan, not as physicians or employers of physicians. ${ }^{22}$ Thus it appears that the Court has moved back toward the recognition that many treatment decisions made by an MCO are pure eligibility decisions preempted by ERISA. Similarly, in Sarkisyan's case, CIGNA, acting as the administrator for the employer's self-funded plan, made an eligibility determination based on plan coverage, and ERISA would have likely preempted any state law tort claim. Sarkisyan's family would therefore be limited to reimbursement for any treatment wrongfully denied, a useless remedy to a family who has just lost a daughter due to that denial.

\section{B. Other Factors Leading the Movement}

All things considered, managed care litigation may indeed be "the tobacco litigation of the turn of the century." ${ }^{23}$ It is clear that public favor of managed care is low, but how the industry got to such a state is less certain. ${ }^{24}$ Managed care initially developed as a response to rising health care costs in the $1980 \mathrm{~s} .{ }^{25}$ Corporations that had been induced to provide health care to employees by labor organizations in the 1950 s became faced with increasing healthcare costs that were a huge drain on their resources. ${ }^{26}$ Complicating the problem was the attitude of employees, many of whom soon came to expect that their employers would provide affordable health care as a benefit of employment. ${ }^{27}$ Moreover, physicians, who essentially controlled the entire system, received payment for each test they ran or each drug they prescribed, which led to patient over-treatment, increased costs, and a resulting

22. Davila, 542 U.S. at 220-21.

23. Allred \& Daniel, supra note 14, at 311.

24. Jensen, supra note 13, at 1347; see also Maura F. Forde, Note, Jones v. Chicago HMO: The Illinois Supreme Court Gives the HMO Industry A Rude Awakening, 32 Loy. U. CHI. L.J. 511, 512 (2001) (discussing how the media exacerbates the problem by bringing delay and denial "horror stories" to the attention of the public). See generally Linda Peeno, Managed Care and the Corporate Practice of Medicine, TRIAL, Feb. 2000, at 18 (considering the severe "lack of ethical, legal, and safety" safeguards for patients, it is "little wonder" that managed care has outraged our country).

25. Jensen, supra note 13, at 1348-49.

26. Id. at $1347-48$.

27. Id. at 1348 . 
overburden on employers who had to try and manage those costs but who had no expertise to do so. ${ }^{28}$

Under the new managed care scheme, physicians receive a flat fee to cover all patient care. ${ }^{29}$ Such a fee system aligns physician interests with those of the employers rather than the patients and removes the physicians' control over the healthcare system. ${ }^{30}$ Whereas the prior system encouraged overtreatment, the current managed care system arguably encourages physicians to under-treat; physicians who order fewer tests or prescribe fewer drugs can keep the entire fee received from the managed care entity. ${ }^{31}$ Under a managed care scheme, there are still Preferred Provider Networks that work under the traditional fee-for-service model, but the more modern trend is toward the capitation system. ${ }^{32}$

Possibly the most polarizing feature of managed care is its system of utilization review to cut costs. "Managed care reviewers," who in some cases are not even doctors, usually work for the managed care entity and often end up determining what treatment the patient actually receives. ${ }^{33}$ In Sarkisyan's case, CIGNA employed pre-procedure or pre-service review to determine whether Sarkisyan's employer should cover the liver transplant. ${ }^{34}$ The determination was made using medical evidence like the guidelines provided by the American Association for the Study of Liver Diseases and the American Society of Transplantation, and internal and independent external review by physician transplant experts. ${ }^{35}$ Though utilization review decisions are essentially coverage decisions - making a determination as to whether a treatment is experimental and not covered under the plan-they are also inherently medical decisions, "because in most instances they determine whether or not the insured will receive medical treatment." ${ }^{36}$ Many saw the

\footnotetext{
28. Id. at 1349 .

29. Id. (providing that this new system is known as "capitation").

30. $I d$.

31. Id.

32. Diana Joseph Bearden \& Bryan J. Maedgen, Emerging Theories of Liability in the Managed Care Industry, 47 BAYLOR L. REv. 285, 297-98 (1995).

33. Jensen, supra note 13 , at 1350.

34. As opposed to retrospective review, where an insurer denies payment for care already provided, preprocedure or preservice review occurs prior to a procedure or service to determine whether that service is medically necessary or experimental, and thus not covered by the plan. FURROW ET AL., supra note 2, at 627.

35. Statement from Jeffrey Kang, M.D., M.P.H., Chief Medical Officer, CIGNA HealthCare, to Employees and the Media (Dec. 31, 2007), available at http://newsroom.cigna.com/article display.cfm?article_id=840.

36. FURROW ET AL., supra note 2, at 628.
} 
injection of this element into the mix as an invasion of the sanctity of the patient-doctor relationship. ${ }^{37}$

Despite the criticisms, managed care achieved what employers and society had set out for by keeping health care costs down. ${ }^{38}$ Yet it is this costcontainment focus and for-profit feature that has also prompted such public scorn. Society does not want financial prowess or wherewithal to influence or impact its health. Anyone facing a health crisis would certainly hope to have access to the best treatments available, regardless of cost. The reality, however, is that healthcare resources are scarce and that treatment often imposes large costs that someone must pay.

Furthermore, the lack of transparency in the healthcare industry itself prompts fear in the hearts of patients who rely on a physician's expertise and knowledge..$^{39}$ That is to say, the fact that physicians are conflicted over patient treatment because of financial disincentives in an industry that many lay people do not understand has caused many to point the finger at the industry deemed responsible for this breakdown - the managed care industry itself.

\section{The Rise of the Criminal CASE?}

Criminal homicide results from either one's intentional acts that result in death, the conscious disregard of the high probability that one's actions will cause death, or the failure to act to prevent death when action is required. ${ }^{40} \mathrm{It}$ would seem that an MCO's denial of life-saving treatment when such treatment is required fits squarely within the third definition, namely, an omission punishable as criminal homicide. ${ }^{41}$ So why have criminal prosecutors failed to target the managed care industry? Problems with the essential

37. Jensen, supra note 13, at 1350.

38. Id. at 1351.

39. See FurRow ET AL., supra note 2, at 392 (stating that "medical professionals are in a position of dominance with regard to their patients [because] the physician has superior knowledge [and] expertise .... Patients are thus vulnerable ..."); see also Lucian L. Leape, Error in Medicine, 272 J. Am. Med. Ass'N 1851 (1994) (discussing that the medical culture of perfection and infallibility creates incentives for physicians to cover up medical errors).

40. See 40 Am. Jur. 2d $\S 85$ (2008). See generally Joshua Dressler, Understanding Criminal LAw 502-06 (3d ed. 2001) (defining criminal homicide).

41. See John A. Robertson, Involuntary Euthanasia of Defective Newborns: A Legal Analysis, 27 StAN. L. Rev. 213, 217 (1975) (defining guilt of homicide by omission as requiring the following: (1) a legal duty to protect another; (2) a failure to act combined with knowledge or gross negligence; and (3) that such failure be the proximate cause of the death). Robertson continues analyzing criminal liability for homicide by omission, explaining, "if the omission is intentional the person can be prosecuted for first-or second-degree murder depending on the extent of his premeditation and deliberation." Id. at 217-18. 
elements of homicide by omission, along with difficulties in handling the tension between the public benefit and the societal discontent with the industry, seriously complicate the situation and decrease the likelihood that such prosecution would be successful.

\section{A. Duty}

In the case of criminal homicide by omission, there must be a legal duty to act. ${ }^{42}$ Such a duty exists through express or implied contract, such as when a doctor agrees to care for her patient. ${ }^{43}$ Once the contract to provide services exists, the provider has an "obligation to perform those services properly." 4 Thus, courts have imposed criminal liability when the failure to provide services leads to death. ${ }^{45}$ As the insurer of the subscriber, the insurer's legal duty to the insured arguably arises out of contract principles as well. ${ }^{46}$ Even though the contract may be one entered into between the employer and the insurer, a duty on the part of the MCO may arise if the insured is considered a third party beneficiary to the contract. ${ }^{47}$ Similar to hospital administrators who are under a contractual obligation with the hospital to assure that the health and safety of third party beneficiary patients are protected, MCOs would seem to be under a contractual obligation with the employer to manage the care of the insureds. ${ }^{48}$ The more control an MCO exerts over the physician, the more established the MCO's duty to the subscriber. ${ }^{49}$ Even in CIGNA's

42. See Model Penal Code $\S 2.01$ (3)(b) (Official Draft 1962) (“[A] duty to perform the omitted act is otherwise imposed by law."); see also Jones v. United States, 308 F.2d 307, 311 (D.C. Cir. 1962) ("[F]inding of legal duty is the critical element of the crime charged.").

43. Joshua Dressler, Some Brief Thoughts (Mostly Negative) About Bad Samaritan Laws, 40 SANTA ClARA L. Rev. 971, 976 (2000). There are generally three other circumstances when the law invokes a duty to act: (1) when there is a "special relationship" such as between a parent and child; (2) when a person creates a risk for another and then fails to prevent that harm; or (3) when a person who has no legal duty to act voluntarily comes to the aid of another but fails to provide further aid or assistance and, as a result of this failure to act, puts the at-risk individual in a worse position than if no assistance had been undertaken. Id. at 975-76. (1988).

44. Arthur Leavens, A Causation Approach to Criminal Omissions, 76 CAL. L. Rev. 547, 557

45. See Jones v. United States, 308 F.2d 307, 310 (D.C. Cir. 1962) (baby-sitter guilty of homicide for failure to feed infant); State v. Brown, 631 P.2d 129, 131-32 (Ariz. Ct. App. 1981) (nursing home operator under duty to feed and care for patient); People v. Montecino, 152 P.2d 5, 13 (Cal. 1944) (homecare nurse under duty to provide or obtain necessary medical care for patient in her care).

46. FURROW ET AL., supra note 2, at 576-80.

47. See Robertson, supra note 41 , at 226.

48. See id.

49. Bearden \& Maedgen, supra note 32, at 302 (maintaining that HMO-established utilization management programs can impact the control element necessary to establish contractual liability). 
case, where the MCO "merely" made coverage determinations based on plan provisions, the company's use of utilization management certainly impacted the actual treatment Ms. Sarkisyan received. ${ }^{50}$ Nevertheless, whether this contract between an MCO and the insured party truly exists may not be as clear as it seems.

Often, as in the case of Nataline Sarkisyan, where the MCO entered into an Administrative Services Only ("ASO") contract with the employer, the MCO "provides administrative services and coordinates clinical procedures, including determining if a plan covers a specific, proposed treatment." ${ }^{51}$ As an administrator, an express contract exists between the MCO and the employer, but not between the MCO and the insured. Furthermore, the insurer, like CIGNA in this case, does not fund or pay for the clinical care: the employer does. ${ }^{52}$ In order to serve its client - the self-funded employer-the insurer must administer the plan according to the employer's specifications. Thus, any duty owed by the MCO to the insured may be limited to the express terms of the contract, which often contain numerous exceptions. Because of its risk pooling function, all types of insurance carve out exceptions to lower the overall risk and to ensure that there are enough financial resources to provide for all of its covered beneficiaries. ${ }^{53}$

If the insurance contract has these exceptions, usually in the form of numerous carve-outs for experimental treatments, an MCO may argue that the "level of necessary care becomes extraordinary in the case of experimental treatments." ${ }^{54}$ There is little case law on point regarding the standard of care an insurer might owe to an insured with respect to the nuances of the plan, but typically, "an individual is required to provide only the level of care that society may reasonably expect, given the risk, available means, and likelihood of benefit in the precise circumstances facing the actor." 55 To complicate things further, in reality most contracts do not define the term "medical

50. See id.

51. Kang, supra note 35 .

52. Id.

53. FURROW ET AL., supra note 2, at 572 ("Health insurance essentially involves transferring risk from those insureds, who account for most of health care costs, to low-risk insureds, who pay most of the premiums, through the medium of the insurer."); see also Zinberg, supra note 5 ("Insurers are obliged to preserve resources to pay for subscribers' medical needs. That is, they need to direct a limited pool of cash to treatments most likely to work. If they pay for lots of unproven, experimental, expensive procedures ... they have less left to pay for proven therapies for other patients.").

54. Robertson, supra note 41 , at 235.

55. Id. 
necessity" and therefore exceptions and denials can seem arbitrary and clouded with the possible taint of financial motivations. ${ }^{56}$

An example of ordinary versus extraordinary care can be found in Barber v. Superior Court. ${ }^{57}$ The state of California charged an internist and a surgeon with homicide for allowing a comatose patient to die by withholding his intravenous nourishment. ${ }^{58}$ The court dismissed the charges, holding that the doctors were not under a legal duty to continue providing life-sustaining fluids where "there was no reasonable chance that further treatment would provide the patient with benefits that outweighed the treatment's burdens." 59

By providing experimental treatments outside the scope of the plan to a few sick insureds, the insurer takes money away from the relatively healthy patients, thus diminishing the funds available to the general pool. As in the case of Ms. Sarkisyan, "[i]deally, everyone who can benefit from an organ transplant would receive one ... [,] [b]ut with more patients than available organs, some form of allocation procedure involving administrative judgments is inevitable. ${ }^{\circ 0}$ The insurer fills this role by making the judgment call through its reading of the employer's health insurance contract and through medical expertise. ${ }^{61}$ Acknowledging that experimental treatments "are a complex social issue," Jeffrey Kang, CIGNA's Chief Medical Officer, went on to say that "[t]ransplants are especially complex [determinations] given the scarcity of organs themselves ... [;] there are more than 98,000 people waiting for an organ transplant — nearly 17,000 specifically for liver transplants." ${ }^{62}$

The MCO's advisory role is an extremely important one when health resources are scarce. MCOs contain costs through various methods, including utilization review, the capitation system, and provider networks, among others. ${ }^{63}$ In fact, in Pegram v. Herdrich, the Supreme Court, noting the nature

56. FURROW ET AL., supra note 2, at 629-30 (discussing the problems with defining medical necessity). CIGNA's Chief Medical Officer would likely reply that there is no such taint in Sarkisyan's case, as CIGNA did not fund and was not financially responsible for payments under the plan. See Kang, supra note 35. However, CIGNA does have a financial incentive to retain the business of its often large corporate clients, and saving those clients money almost certainly plays a role in CIGNA retaining that business.

57. 195 Cal. Rptr. 484 (Cal. Ct. App. 1983).

58. Id. at 486

59. Id. at 491 .

60. Scott Gottlieb, Opinion, Edwards and Organ Transplants, Wall St. J., Jan. 11, 2008, http://online.wsj.com/article/SB120001235968882563.html.

61. Id.

62. Kang, supra note 35 (citing to the transplant list at http://www.unos.org and the liver transplant list at http://www.optn.org/data/).

63. See supra Part I.B (discussing capitation system and utilization review); see also FURROw ET 
of an HMO's risk-pooling and economic function, ruled that under ERISA, treatment decisions made by the HMO do not need to be solely in the interest of the participants and beneficiaries.$^{64} \mathrm{HMOs}$, according to the Pegram Court, were free to continue using physician incentives and treatment rationing through utilization review. ${ }^{65}$ Though ERISA applies only to civil suits, this language may impact the duty analysis in criminal contexts in light of the unique role that for-profit MCOs play in the healthcare environment.

Utilization review and other MCO practices work not only to control costs but also to provide better quality. There is evidence that more treatment is not necessarily better treatment. ${ }^{66}$ Dr. David Eddy, a health economist with Duke University, commented on a 1993 California civil case that produced an $\$ 89.3$ million award for the family of a woman denied an experimental treatment for the breast cancer that ultimately killed her. ${ }^{67} \mathrm{He}$ expressed his concern that if the "[award was] interpreted to mean that investigational procedures should be covered, that is a disaster, not just for the cost of health care but also for the quality of health care." ${ }^{98}$ An MCO's primary function in using utilization review is to avoid harmful treatments by providing a barrier to such unproven treatments. ${ }^{69}$

This tension between more treatment and better treatment complicates the duty analysis. Does the insurer have a duty to provide more treatment or to provide what is considered the better treatment? In the case of Nataline Sarkisyan, CIGNA deemed the transplant unproven in its medical benefit and ineffective as treatment and thus recommended that her parent's employer not

AL., supra note 2, at 571 (discussing different provider networks).

64. Pegram v. Herdrich, 530 U.S. 211, 220 (2000). The Court elaborated further when it said, "No HMO organization could survive without some incentive connecting physician reward with treatment rationing." $I d$.

65. Id.

66. See Riser v. Am. Med. Int'1, Inc., 620 So. 2d 372, 378 (La. Ct. App. 1993) (where a patient died as a result of a procedure that would have had "no practicable benefit to the patient"); see also AvEDIS Donabedian, The Definition of Quality and Approaches to its Assessment (Explorations in QuAlity Assessment And Monitoring, Vol. 1) 6-7 (1980) (“'P] roviding excessive care to some [leaves less for] society to offer to others who may need it more" and such "redundant care, even when it is harmless, indicates carelessness, poor judgment, or ignorance"); Mark R. Chassin et al., The Urgent Need to Improve Health Care Quality, 280 JAMA 1000, 1000 (1998) ("Poor quality care can be caused by underuse, overuse, or misuse."). A1.

67. Erik Eckholm, $\$ 89$ Million Awarded Family Who Sued H.M.O., N.Y. TimEs, Dec. 30, 1993, at

68. $I d$.

69. Id. Utilization review is the MCO's process of determining the necessity of medical care on a case by case basis in order to contain costs by eliminating unnecessary, and thus wasteful, care. FURROW ET AL., supra note 2, at 627. 
cover the procedure. ${ }^{70}$ After an appeal and an internal review, CIGNA sought external review by an oncologist and transplant surgeon. ${ }^{71}$ These experts allegedly agreed that the transplant exceeded appropriate risk and that benefits were not supported by medical literature. ${ }^{72}$

Further complicating the duty analysis is that a duty arising from a contract in the civil arena is not necessarily analogous to the duty owed in a criminal context. ${ }^{73}$ Some have suggested that criminal liability be limited to where there is a duty aimed at "preserving life." ${ }^{.74}$ This duty is more easily attributable to physicians and less likely to apply to managed care entities who must manage care in order to preserve resources for all beneficiaries. Moreover, it is entirely unclear what constitutes a life preserving duty and when one has such a duty. Even if an insurer has a duty to preserve life, it may not have a legal duty to pay for any unproven measure that might preserve life. In homicide-by-omission crimes, the action that one failed to take must have been one that was required, not merely one that was foregone. ${ }^{75}$ The scope of the duty to preserve life is therefore somewhat ambiguous.

\section{B. Causation}

In addition to the legal duty to act, another essential element of homicide by omission is causation. The causation element required in a criminal case is more than just the actual (or "but for") causation required in civil cases. ${ }^{76}$ Even if the omission is the actual cause of the harm, it must also be the proximate (or "legal") cause of the result. ${ }^{77}$ Proximate cause requires

70. Gottlieb, supra note 60.

71. Id.; see also Kang, supra note 35.

72. Id.

73. Leavens, supra note 44 , at 555.

74. Id. at 556.

75. See supra Part II.

76. See DRESSLER, supra note 40, at 182-83 (stipulating that conduct is considered the actual cause of a particular result if the result would not have happened in the absence of such conduct; this requirement is commonly referred to as the "but for" test); see also People v. Warner-Lambert Co., 414 N.E.2d 660, 665-66 (N.Y. 1980) (citing People v. Kibbe, 321 N.E. 2d 773, 776 (N.Y. 1974), in which the court held that there was no criminal liability for employee deaths in a plant explosion because "the defendants' actions must be a sufficiently direct cause" of the death); Leavens, supra note 44 ("[T] he law differentiates among the many possible 'but for' causal forces, identifying some as 'necessary conditions' - necessary for the result to occur but not its direct 'cause' - and recognizing others as the 'direct' or 'proximate' cause of the result.").

77. Peter T. Edelman, Corporate Criminal Liability For Homicide: The Need to Punish Both the Corporate Entity and its Officers, 92 Dick. L. Rev. 193, 210 (1987). 
foreseeability of "each particular event . . . leading up to the ultimate result." Though this seems simple enough, the way the law evaluates which forces are the proximate cause is not always entirely objective or clear. ${ }^{79}$ The analysis becomes further complicated when deciding "whether and to what extent a failure to act is the legal cause of a harm." 80

In determining what force is the proximate cause of the resulting harm, the typical and simplest scenario falls into the "physical cause and effect model." ${ }^{" 81}$ Such a paradigm consists of an identifiable physical force acting to change the current state of affairs. ${ }^{82}$ In cases of omissions, the cause and effect relationship is somewhat less clear because one simply allows the status quo to continue.$^{83}$ Thus, although an actor may indeed be the "but for" cause of the harm, so are many other actors or forces.$^{84}$ For example, in the case where an MCO fails to treat a sick patient who ultimately dies, it can be said that "but for" the MCO's failure to pay for the treatment, that patient would have lived. It can also be said, however, that "but for" the original illness the patient would have lived without requiring the treatment at all. In Nataline Sarkisyan's case, many factors could have been the "but for" cause of her death: although being taken off life support was the final physical push closest in time to her death, complications from her bone marrow transplant put her in the coma, which prompted doctors to put her on life support. Furthermore, her initial leukemia treatment was what had required the bone marrow transplant in the first place. It is obvious that the denial of the liver transplant fits somewhere in the causal analysis but it is unclear how much of a role it actually played.

78. Id. at 211.

79. The law of proximate cause thus attributes causal responsibility for a criminal harm to some acts but not others even though the harm in question could only have resulted from all of the conduct taken together. See id. at 210-11; see also State v. Cox, 351 P.2d 472, 474-75 (Idaho 1960) (holding that the victim's death was causally attributed to the defendant driver who put the victim in peril and not the physician who treated the victim less than skillfully); People v. Kibbe, 321 N.E.2d 773, $776-77$ (N.Y. 1974) (holding that the fact that the victim was struck and killed by a truck did not relieve the defendant of the direct causation attributable to him for leaving the drunken robbery victim on an icy road late at night); Leavens, supra note 44, at 564 ("While much of proximate cause analysis has been framed in language that rings of actual or physical causation, this inquiry is hardly objective.").

80. Leavens, supra note 44 , at 565.

81. Id. at 572 .

82. $I d$.

83. $I d$.

84. See id. at 572-73. 
Professor Arthur Leavens argues that such a view of causation is too limited and thus is fundamentally flawed. ${ }^{85}$ The status quo, he says, encompasses much more than just the state of affairs prior to and immediately after the omission. ${ }^{86}$ It includes "expected patterns of conduct, including actions designed to avert certain unwanted results." ${ }^{87}$ Failure to take action to avoid such results should also be seen as disturbing the status quo. "When such a failure to act is a necessary condition (a "but for" cause) of a particular harm, then that failure fairly can be said to cause that harm." ${ }^{\text {89 }}$ Leavens maintains that omissions do indeed fall into the cause-and-effect model..$^{90}$ According to such a view, an insurer who fails to pay for a preventative treatment that might prolong life would be said to proximately cause the ensuing death as long as payment for that treatment is expected. Societal expectations notwithstanding, the contract between the MCO and the employer often excludes certain treatments from coverage, often by only offering to cover that which is deemed to be "medically necessary."

The law seems to agree with Leavens. Most courts have decided that accelerating any death is criminally punishable. ${ }^{91}$ In the CIGNA scenario, the denied treatment potentially could have prolonged life for a significant period of time. ${ }^{92}$ Thus, CIGNA would hardly be able to argue that Sarkisyan was going to die anyway because of her pre-existing condition. "As the period shortens, however, the distinction between ordinary and extraordinary duties of care becomes relevant." ${ }^{93}$ Failing to provide "extraordinary care" (care that

\section{Id. at 573 .}

86. $I d$.

87. Id. Leavens states the following example:

When, for example, a driver parks a car on a steep hill, it is normal to set the parking brake and put the car in gear. If the driver forgets to do so and the car subsequently rolls down the hill, smashing into another car, we would say that the failure to park properly was a departure from the status quo. This failure, not the visibly steep hill or the predicate act of pulling the car to the curb, was the cause of the collision.

Id.

88. $I d$.

89. Id. ("In the [earlier] example, the driver's failure to park the car in a proper manner caused the accident as surely as if he had actually driven his car into the other."); see also supra text accompanying note 79 (examining the legal cause of harm).

90. Leavens, supra note 44 , at 573.

91. Robertson, supra note 41, at 237; see also 40 AM. JuR. 2d Homicide $\S 19$ ("It is equally well settled that the consequences of an act which is the efficient cause of the death of another are not excused, nor is the criminal responsibility for causing death lessened, by the pre-existing physical condition of the person killed, at the time the act was done. ...").

92. See supra text accompanying note 7.

93. Robertson, supra note 41 , at 237. 
would result in only "a few days or hours [more] of existence") may not be criminally culpable even though it may hasten death. ${ }^{94}$ Again, how much time is required before one is "preserving life" has not been delineated.

In the typical managed care scenario, the MCO simply makes the decision as to whether the insurer, or the employer in a self-insured plan, will pay for the treatment. ${ }^{95}$ This determination is made based on the terms of the insurance contract and whether a particular treatment is "covered." The patient's doctors, and sometimes the hospital caring for the patient, also play a role and owe a duty to the patient. A common defense to the issue of causation is therefore "that the omission of a particular defendant should not legally be considered the cause of [a patient's] death because the patient would not have died had the other persons with a duty of care fulfilled their obligations to him. ${ }^{"}{ }^{96}$ In the case of Nataline Sarkisyan, though CIGNA denied payment for the experimental treatment, the doctors who were pushing for it could have simply provided the treatment and dealt with the issue of payment later. ${ }^{97}$ The omission of the doctors could be viewed as a "sufficiently independent intervening cause to break the causal link between the defendant's act and the resulting death." $" 98$

Professor Robertson argues that there are two problems with the intervening cause argument. ${ }^{99}$ Though a defendant's omission may not be a sufficient condition of a patient's death, it may be a necessary condition. In Sarkisyan's case, CIGNA's "payment" denial was not an actual "treatment" denial and thus not an independently sufficient cause of her death. It was only because her doctors failed to provide the treatment in the first place that the resulting harm occurred. Robertson goes on to argue that even with merely necessary (and not sufficient) causation, those who fail to act should nevertheless be assigned legal causation. ${ }^{100}$ The law in this area, he says, "selects one or more necessary conditions as the legal cause" based on policy

94. Id.

95. See FurRow et AL., supra note 2, at 567. A self-insured plan is one that is not backed by an insurance policy. The employer instead funds and administers its benefit plan (i.e., pays claims covered by the benefit plan from its own money). It may outsource or delegate the administration of the plan to a thirdparty administer (TPA) (often an insurance company), but this TPA does not provide the employer with any financial backing or assume any financial risk associated with the claims.

96. Robertson, supra note 41, at 238.

97. See Whelan, supra note 3 (stating, "It's not enough for the insurer to deny coverage .... The doctors and the hospital—especially a nonprofit institution like UCLA—must decline to work for free.").

98. Robertson, supra note 41, at 238.

99. Id. at 237 (saying that a defendant generally has two defenses to the causation argument). 100. Id. at 238 . 
determinations, such as which actor can "prevent future occurrences of that necessary condition and thus the prohibited result." ${ }^{101}$ Furthermore, the law will assign causation to the actor who "reasonably foresees or expects that others with a duty to act will not intervene," which would here seem to be the insurance company. The MCO, whose purpose is to keep costs down, knows that most doctors will not treat without assurance of payment unless they are legally required to do so. ${ }^{102}$ Under Robertson's theory, the doctors' omission would not be an independent, intervening cause breaking the chain of causation. ${ }^{103}$ In fact, it seems as though the doctors' omissions are very much related to the MCO's omissions, and might even be caused thereby.

The cause-and-effect model at this stage "does not differentiate among various persons who should engage in preventive conduct." 104 In order to determine who should act, the law must set out what the expectations are for each individual or corporation, and only when those individuals fail to act as expected should it be said that the proximate cause element has been met. ${ }^{105}$ Professor Leavens goes on to urge that causation should be "sharply focused" so that moral indignation does not play a role in assigning blame to those who fail to act when not legally required to do so. ${ }^{106}$ The concern over moral indignation almost certainly permeates the duty and causation analysis in the managed care context. ${ }^{107}$ Therefore, it becomes extremely important that expectations are rationally and objectively determined. These expectations, operating against a backdrop of scarce healthcare resources, should reflect and promote policy concerns while staying true to contract principles. ${ }^{108}$ Thus, duty and proximate cause in the managed care arena are inherently intertwined. ${ }^{109}$

101. Id. (he suggests: "[A] bullet fired from a gun is only one of many conditions that must exist for a human death from shooting .... Although firing the gun is a necessary but not sufficient condition of the death, the law justifiably selects that act as the legal cause because the shooting is a point at which social interventions may effectively prevent future deaths by gunfire.").

102. See, e.g., Whelan, supra note 3 (the author, questioning why the hospital did not proceed with the transplant despite the non-payment, questioned a hospital spokesperson who cryptically said that "[t]here have been occasions where UCLA has performed a transplant without compensation" but that payment is always an issue for the patient anyway because of the cost of after-care).

103. Robertson, supra note 41, at 239.

104. Id. at 573 .

105. $I d$.

106. $I d$.

107. See infra Part III; supra notes 12-13 and accompanying text.

108. Leavens, supra note 44 , at 576 (explaining how contract law produces a regularity of performance by formalizing and requiring particular standards of conduct).

109. $I d$. at 575 (suggesting that the duty in the criminal context must rely on "empirically valid expectation[s] that persons in similar circumstances will act to prevent a harm . . . and also a deeply 


\section{Intent}

To prosecute homicide by omission successfully, the person who fails to act must do so "with knowledge or gross negligence." ${ }^{110}$ MCOs are artificial entities and it is therefore difficult to attribute a mental state to them. ${ }^{111}$ However, the law has held corporations criminally responsible for specific intent crimes in the past under several theories. ${ }^{112}$ Typically, a corporation is either responsible for (1) the acts of its employees through respondeat superior, (2) the acts of the highest officials, or (3) "illegal conduct that results from reckless or unreasonable conduct." ${ }^{\prime 13}$

Though most courts agree that the requisite intent can be impugned to the corporate entity, the approach still has its critics. ${ }^{114}$ MCOs are not like other corporations because they often act as intermediaries and perform specific contractual functions. The fact that the MCO may be functioning primarily for the benefit of the employer or for the insured, or for some combination thereof, may make it more difficult to decipher whether any of the MCO's agents or employees had the necessary intent to harm, since working for the benefit of one may oftentimes necessarily harm the other. Thus, without specific statutes or regulatory laws setting standards of conduct for MCOs (aside from ERISA), it will be difficult to impugn the requisite criminal intent to the insurer.

\section{Criminal Prosecution Is Not the Solution}

Aside from problems with fulfilling the elements of criminal homicide, there are policy problems with expanding the criminal law to cover treatment denials by MCOs. Criminal prosecution would represent yet another example

ingrained common understanding that society relies on that individual to prevent the harm").

110. Robertson, supra note 41, at 217; see also DRESSLER, supra note 40, at 102 (describing crimes by omission, Dressler explains that the remaining elements of the offense must be proven, including the "requisite mens rea.").

111. See generally Susan S. Septimus \& Allison L. Spruill, The Phantom of the Corporate Operation: Criminal Liability, HoustOn LAWYER, Nov.-Dec. 1992, at 15; see also Edelman, supra note 77, at 199 (saying that a "corporation has no mind and no soul; therefore, a mental state has no meaning when applied to a corporation").

112. Edelman, supra note 77, at 199.

113. Id. at 199-200.

114. See generally Gregory L. Diskant, Trial Balloon: Rethinking Corporate Criminal Liability, 34 Litigation 2, Winter 2008, at 5, 6 (discussing problems with respondeat superior corporate criminal liability). 
of "citizens and the executive branches of government [] seek[ing] restitution and fundamental social change in the courts after losing in the legislative arena, thus forcing the judiciary branches into the unwise and improper role of policymaker." 115 Yet, unlike other legal industries that have faced aggressive civil litigation and have been changed thereby (e.g., the tobacco, lead paint, and handgun industries), the managed care industry involves questions of federal preemption and damage limitations under ERISA, which further induces plaintiffs to seek redress through criminal sanctions. ${ }^{116}$

Joshua Dressler sees "troubling features" in the current state of homicideby-omission liability. ${ }^{117}$ The general homicide statute contains an active-state element - actus reus - that is defined as the "killing of a human being by another human being." ${ }^{118}$ It is truly difficult to reconcile CIGNA's actions in Sarkisyan's case to this literal language. Although CIGNA may have allowed the leukemia to kill Nataline, it performed no killing act itself. More fundamentally, characterizing the insurer as a killer, and thereby equating its passivity with the doctor or hospital's passivity or with leukemia's uncontrollable effects, "undermines the concept of individual responsibility and authorship of conduct." 119 In Sarkisyan's case, although her doctors were convinced that the transplant would benefit her, they failed to go through with the treatment without payment. ${ }^{120}$ Instead, the hospital required a down payment of Sarkisyan's parents, which they failed to provide. ${ }^{121}$ Though all of the actors seem to be culpable in some sense, the law has failed to carefully define expectations in a situation such as Sarkisyan's. Without such clear standards and expectations, the law can hardly punish actors who are not breaking the law.

Dressler analogizes to a case where a woman named Alice allowed her boyfriend, Bob, to beat her daughter to death without doing anything to stop him. ${ }^{122}$ He suggests that Alice's liability, if any, should be for violation of

115. Jensen, supra note 13.

116. See supra note 14 and accompanying text.

117. Dressler, supra note 43, at 977.

118. Id. at 978 .

119. Id.

120. See supra text accompanying note 97. Furthermore, Jeffrey Kang, CIGNA's medical director, states that the United Network for Organ Sharing, which manages organ transplant waiting lists, requires that patients receive transplants regardless of their financial means. In response to criticism that CIGNA denied Sarkisyan a liver, he said, "[T] he reality is we only denied paying for it." Whelan, supra note 3.

121. Alicia Chang, Bereaved Family to Sue Insurer After Dispute Over Liver Transplant, Boston GLobe, Dec. 22, 2007, at A2.

122. Dressler, supra note 43, at $977-78$. 
some "less serious and narrowly defined statute that compels parents to act to protect the well-being of their children." ${ }^{123}$ Alice should not be deemed a killer, he says, but may be deemed a bad parent. ${ }^{124}$ Similarly, an insurer should be liable for breaching their obligation as an $\mathrm{MCO}$, but should not be labeled a murderer. In cases of omissions, which punish for "nothing rather than something," there is a need for standard, objective criteria to determine criminal culpability. ${ }^{125}$ Dressler suggests criteria such as "the status relationship of the parties, contractual understandings, or the suspect's personal connection to the emergency by having created the initial risk." 126

Dressler also sees problems with the current state of "commission-byomission" crimes. ${ }^{127}$ More specifically, he doubts the logic of equating "positive duties with negative ones." 128 The criminal law punishes for legally culpable acts or non-acts, not for bad character. ${ }^{129}$ "At a minimum, there is a serious risk that juries will inadvertently punish people for being (or seeming to be) evil or 'soulless,' rather than for what occurred on a specific occasion." 130 This risk of bias is arguably even greater in the case of an MCO. Almost every member of society has some viewpoint about MCOs and their proper role, yet few of those same people know the intricacies of the business itself. Though it may seem impossible to say that the law would punish an MCO for its "bad character" (since the MCO is not an individual, it is not capable of having a character in the ordinary sense of the word), in reality this is probably even more likely to happen than with an individual actor. When an individual is accused of a crime, jury members can often empathize as fellow human beings, recognizing human limitations and shortcomings. MCOs are unlikely to garner any such support.

Along the same morality line, criminal liability can hardly make MCOs virtuous. "It is worth remembering that the criminal law is not a cure for all of our problems." ${ }^{131}$ Like litigation against the tobacco, lead paint, and handgun industries, managed care prosecution represents punishment for

123. Id. at 978 .

124. $I d$.

125. Id. at 984

126. $I d$.

127. Id. at 979 .

128. Id. Thus, the "duty to act to make the world better" is as demanding a legal duty as the "duty not to actively make the world worse." Id.

129. Id. at 981

130. Id. at 982 .

131. Dressler, supra note 43, at 989. 
providing legal products and services. ${ }^{132}$ Unlike these other industries, managed care serves an important societal function by rationing scarce healthcare resources and by keeping costs low.

One would think that "the government [would] always win[] when it chooses to charge a corporation with a crime" due to the doctrine of respondeat superior, which imputes to the corporation any wrongdoing of an employee. ${ }^{133}$ Though this doctrine is quite useful in civil disputes, it does not lend itself so easily to application in the criminal context, where individuals are typically held accountable and punished for their acts or omissions. ${ }^{134}$ Furthermore, "Congress has provided no guidance whatsoever about how to determine which acts of which natural persons should be imputed to the artificial 'person' of the corporation for purposes of determining whether it has committed a crime." ${ }^{\prime 35}$ Many scholars argue that punishing a corporation criminally will not deter criminal behavior, since corporations "have no soul to be damned and no body to be kicked."136 "The concept of a fictional economic entity simply does not mesh with the four goals of criminal law: deterrence, retribution, incapacitation, and rehabilitation." 137

Furthermore, "[c]riminal prosecution of such [artificial beings] . . . does not punish the wrongdoers . . . it punishes the stockholders." "I38 In fact, the policy behind placing limitations on ERISA damages is that, "because many benefit plans are self-funded, it is the workers' money that would pay the damages." 139 Also, since the corporation is an artificial entity, it cannot be incarcerated. ${ }^{140}$ Therefore, large fines will replace prison sentences, and the impact of such penalties will "result in low dividends, fallen stock values, and

132. Jensen, supra note 13 , at 1337.

133. Diskant, supra note 114, at 6 (stating that because of the doctrine of respondeat superior, the corporation is charged with the criminal conduct of any wrongdoing employee).

134. Id.

135. $I d$.

136. Laurel J. Harbour \& Natalya Y. Johnson, Can a Corporation Commit Manslaughter? Recent Developments in the United Kingdom and the United States, 73 DEF. Couns. J. 226, 227 (citing Stanley S. Arkin, Corporate Guilty Plea, N.Y.L.J., Oct. 10, 1985, at 28). See generally John E. Stoner, Corporate Criminal Liability For Homicide: Can the Criminal Law Control Corporate Behavior?, 38 Sw. L.J. 1275 (1985).

137. Stoner, supra note 136 , at 1286.

138. Diskant, supra note 114, at 6 (citing to a speech by U.S. District Court Judge, Lewis A. Kaplan, who dismissed criminal charges against thirteen former KPMG employees in United States v. Stein, 495 F. Supp. 2d 390 (S.D.N.Y. 2007) (Hon. Lewis A. Kaplan, Address to the Commercial and Federal Litigation Section, New York State Bar Ass'n (Jan. 24, 2007), http://nysbar.com/blogs/comfed)). Many MCOs, including CIGNA, trade stock on international exchanges.

139. Resides, supra note 14.

140. Edelman, supra note 77, at 198. 
layoffs." ${ }^{141}$ The corporate constituent groups affected (i.e., the officers, directors, employees, and shareholders), may not even be the same groups in place at the time of the wrongdoing. ${ }^{142}$ Furthermore, fines are likely to be passed on to consumers as a cost of doing business. ${ }^{143}$ Thus, society at large ends up paying the greatest price, especially in the context of health care, if MCOs are forced into bankruptcy.

Other scholars argue that litigation aimed at shaping policy, especially in the public health arena, is not effective. ${ }^{144}$ Public health advocates have resorted to litigation in areas of tobacco regulation and gun control, "perhaps out of frustration with the inability to achieve desired public health goals through the legislative branch of government." ${ }^{145}$ ERISA is arguably yet another area where the legislative branch has fallen short. However, there is an important difference: by drastically limiting plaintiffs' damages, ERISA has cut off the public health advocates' litigation alternative to shaping public policy. ${ }^{146}$ The criminal law therefore seems to be the only litigation alternative. But many believe that litigation has had a negative impact on consumer health and is a primary reason for increased health care costs. ${ }^{147}$ The managed care entity was created as a market response to control what seemed to be uncontrollable health care costs prior to the 1980s. ${ }^{148}$ Ironically, the result of large fines from criminal liability may "return Americans to the system of health care that they rejected [almost thirty] years ago." ${ }^{149}$ Unlike the tobacco manufacturers who marketed a product that they knew was harmful to the public in order to make a profit, managed care companies "market a product that helps rather than hurts." ${ }^{50}$ Targeting such an industry

141. Harbour \& Johnson, supra note 136, at 233.

142. $I d$.

143. Health care spending is expected to rise to more than $\$ 4$ trillion by 2017. See Health Care Spending to Rise to $\$ 4.3$ Trillion (Feb. 26, 2008), available at $\mathrm{http}: / / \mathrm{www} . \mathrm{msnbc} . \mathrm{com}$.

144. Peter D. Jacobsen \& Soheil Soliman, Litigation as Public Health Policy: Theory or Reality?, 30 J.L. MeD. \& EThics 224, 224 (2002).

145. $I d$.

146. See supra text accompanying note 14 .

147. Allred \& Daniel, supra note 14, at 309 (citing to a statement by the President of the American Association of Health Plans (AAHP) and a AAHP-commissioned analysis which concluded that twentyseven cents of every new dollar spent on health care in 2001 was "driven by litigation, government mandates and regulation and waste, fraud and abuse").

148. Jensen, supra note 13, at 1336.

149. Id. at 1337.

150. Id. at 1363 . 
with litigation in order to shape policy may end up crippling an industry that undeniably serves a public purpose. ${ }^{151}$

Furthermore, our Constitution sets roles for each governmental body, and it is the legislature who is charged with shaping public policy. The courts should be limited to interpreting those policies. ${ }^{152}$ Courts are ill equipped to devise complex regulatory schemes, which would be necessary in the managed care arena. ${ }^{153}$ The Pegram Court noted that the legislative process is the "preferable forum for comprehensive investigations and judgments of social value, such as optimum treatment levels and health-care expenditure."154 Arguably, even the legislature has failed to regulate in this area out of apathy for the complexity of the healthcare industry. The failure of other branches often drives litigation as public policy, but such an argument does not make the courts any more equipped to shape policy. ${ }^{155}$ ERISA may by seen as both a failure and a reflection of the legislature allowing itself to be influenced by the powerful insurance lobby.

While corporate criminal liability still remains controversial, criminal liability for MCOs is appealing because MCO misconduct has the ability to inflict tremendous pain and injury, both in terms of human suffering and financial loss. ${ }^{156}$ "Additionally, because the current tort and regulatory penalties apparently have not chilled MCO misconduct, legislators and prosecutors are looking to criminal prosecutions to vindicate state interests in the delivery of health care and the protection of citizens." ${ }^{157}$ However, civil litigation can scarcely achieve all the policy goals society seeks. For example, in tobacco litigation, most states hoped to convince the industry to agree to vast regulation, advertising cutbacks, and reimbursement; yet, ultimately they only achieved "pecuniary damages, the goal that litigation is most suited to provide." 158 Criminal prosecution is even less likely to achieve sweeping reform. ${ }^{159}$ For example, a former federal prosecutor argues that a corporate indictment inevitably leads to a guilty plea, large fines, and more headlines,

151. $I d$.

152. Id. at 1380 .

153. Id.

154. Pegram v. Herdrich, 530 U.S. 211, 221 (2000).

155. Jensen, supra note 13 , at 1382.

156. Brian Wilson, Tough Love: The Emergence of Criminal Statutes and Disciplinary Actions Against Managed Care Plans for Inadequate Care, 18 J. ContemP. Health L. \& Pol'y 53, 60 (2001).

157. Id.

158. Jensen, supra note 13, at 1364.

159. See generally Diskant, supra note 114, at 5 (arguing that because prosecutors always win in the area of corporate crime, the time has come to cut back on the prosecution of corporate criminals). 
none of which guarantee widespread industry change. ${ }^{160}$ Furthermore, only corporations with nothing to lose can afford to contest charges in court. ${ }^{161}$ These settlements will also likely reflect only the interests of the litigants, and are thus a poor reflection of the public interest. ${ }^{162}$ It is also worth noting that as a result of the tobacco settlement, share prices for tobacco companies actually rose, resulting in even more profit for the industry. ${ }^{163}$ The benefit of any criminal sanctions is therefore quite uncertain.

Perhaps most unfulfilling about imposing criminal sanctions on the managed care industry is the lack of direction such prosecution provides to MCOs that are actually looking to structure their companies to avoid such punishment. ${ }^{164}$ This concern is even greater given the nature of MCOs as forprofit entities serving an important public function. Without legislatively imposed regulations and expectations, MCOs will continue to try to find a way to operate profitably.

\section{OTher Solutions}

There is an obvious need for Congress to address the shortcomings of ERISA. Although the courts have recently been more progressive in avoiding preemption and allowing more suits to proceed in state court, there are still many questions about ERISA's exact limits on the state's role in health insurance. ${ }^{165}$ So far, the courts have recognized a "presumption against [ERISA] preemption where the statute at issue addresses a historic police power of the states - namely, a matter of health and safety." ${ }^{166}$ Some states have been testing the boundaries of this presumption through laws aimed at curbing MCO misconduct. ${ }^{167}$ Statutes like the Texas Health Care Liability Act permit lawsuits by individuals against MCOs for damages caused by a failure

160. Id.

161. Id. (Diskant argues that "unlike drug dealers or the mob, corporations rarely put prosecutors to the obligation of actually proving to a jury that a crime was committed.").

162. Jensen, supra note 13, at 1381.

163. Id. at 1378.

164. Wilson, supra note 156, at 94.

165. Id. at 66 .

166. Parver \& Martinez, supra note 9, at 226 (citing Corporate Health Ins., Inc. v. Tex. Dep't of Ins., 12 F. Supp. 2d 597, 616 (S.D. Tex. 1998)).

167. Id. at 233. Oregon's Patient Protection Act gives insureds who are denied treatment the right to a full appeals process. 1997 Or. Laws 101. Texas' bill of rights gives insureds whose treatment is delayed or denied the right to sue their insurer. Tex. Civ. Prac. \& Rem. Code AnN. §§ 88.001-.003 (Vernon 1997 \& Supp. 1998). 
to exercise ordinary care when making health treatment decisions. ${ }^{168}$ The Illinois HMO Act provides a right to secure an independent medical review of what constitutes a medically necessary treatment. ${ }^{169}$ If this independent review concludes that a treatment is necessary, the HMO must provide the service. ${ }^{170}$ The Illinois act was challenged as preempted by ERISA, but the Supreme Court rejected the argument. ${ }^{171}$ Although these laws seem to be going in the right direction, they are far from sufficient, and it is worth noting that none of them would have actually helped Nataline Sarkisyan, as her plan was self-insured and thus not subject to state insurance laws. ${ }^{172}$

Though failing to go so far as to clarify or amend ERISA, Congress has responded to the concerns over managed care's cost containment policies through several failed bills aimed at establishing a patient bill of rights. ${ }^{173}$ Though none of these measures passed, a failed version of the bill did help to facilitate private lawsuits against HMOs and insurance companies by inspiring states to provide for such causes of action. ${ }^{174}$

More appropriate than a patient bill of rights establishing a state right to sue would be a complete Congressional overhaul of ERISA. In the case of Corporate Health Insurance v. Texas Department of Insurance, the Fifth Circuit Judge, recognizing that the Supreme Court had "gone as far as it can go," urged Congress to act "to further define what rights a patient has when he or she has been negatively affected by an HMO's decision to deny medical care ... and to enact legislation that ensure[s] every patient has access to that care." 175 Congress should federally mandate independent review procedures and provide for such independent review boards in each state. These boards should be made up of neutral physicians of specified credentials who are not affiliated with the managed care entity. If the independent review board rules in an insured's favor, the services should be provided and the insured should be reimbursed for any out of pocket costs. ${ }^{176}$ Such determinations should be

168. Parver \& Martinez, supra note 9, at 225; see also Tex. Civ. Prac. \& Rem. Code Ann. $\S \S 88.001-.003$ (Vernon 1997 \& Supp. 1998).

169. Ketterman, supra note 14 , at 67 . The statute mandates such a review when the HMO and the primary care physician disagree over a course of treatment. Id. See 215 ILl. Comp. StAT. AnN. 125/4-10 (LexisNexis 2000).

170. 215 Ill. Comp. Stat. Ann. 125/4-10 (LexisNexis 2000).

171. Rush Prudential HMO, Inc. v. Moran, 536 U.S. 355, 355 (2002).

172. Costs on the Rise, Investor's Bus. Daily, June 24, 2002.

173. H.R. 216, 106th Cong. (1999); S. 6, 106th Cong. (1999).

174. Parver \& Martinez, supra note 9, at 232.

175. 12 F. Supp. 2d 597, 616 n.7 (S.D. Tex. 1998).

176. California has adopted a similar state law. See CaL. Civ. Code $\S 3428(k)(1)$ (West 2007). 
made swiftly within a statutorily defined time limit, and expedited decisions should be available in emergency cases like the Sarkisyan case. ${ }^{177}$ If denied, such denials should be provided in writing with data supporting the determination. This independent appeals process should be exhausted before an insured can bring suit. However, if bodily injury is imminent because of the denial or delay, Congress should provide a way for insureds to obtain judicial review of their case.

Furthermore, Congress should adopt a statutory definition of "medical necessity." " definition could not possibly be applicable in all cases. Nevertheless, it should be clear enough so as to provide guidance to MCOs in carving out treatments under their plans, and some level of statutorily defined deference should be given to the treating physician. ${ }^{179}$ Finally, ERISA should provide for punitive damages in the case of gross deviation from the regulatory requirements. Because the regulations provide patients with redress before injury, litigation against MCOs would probably not increase in any unmanageable manner.

\section{CONCLUSION}

The criminal prosecution of MCOs will simply not achieve the sweeping reform of the industry that society hopes to gain through litigation. Whether it be through patients' rights legislation or an overhaul of ERISA, it is clear that Congress needs to act. If Congress seeks to protect the obvious public benefit that flows from MCOs, it needs to either set standards as to how they should make or deny treatment decisions or provide a federal review mandate with a truly independent review board. ${ }^{180}$ Since Congress seems to be concerned that uniform laws be applied in the managed care context, it should establish a uniform review procedure, which would protect the public before treatment is denied. This would avoid litigation that would likely raise the cost of health care to the consumer and cripple an industry that, on the whole, greatly benefits the public.

177. See FurRow ET AL., supra note 2, at 629.

178. See id. at 629-30 (discussing states that have adopted a formal definition of the term).

179. Id. at 630 .

180. See Ketterman, supra note 14, at 71 . 